\title{
INTERFERENCE OF VACCINAL ANTIBODIES ON SEROLOGICAL DIAGNOSIS OF LEPTOSPIROSIS IN VACCINATED BUFFALO USING TWO TYPES OF COMMERCIAL VACCINES
}

\author{
Geraldo de Nardi Júnior ${ }^{1}$; Margareth Elide Genovez ${ }^{1 *}$; Marcio Garcia Ribeiro ${ }^{2}$; Vanessa Castro ${ }^{1}$; \\ André Mendes Jorge ${ }^{2}$
}

${ }^{1}$ Centro de Pesquisa e Desenvolvimento de Sanidade Animal, Instituto Biológico, São Paulo, SP, Brasil; ${ }^{2}$ Faculdade de Medicina Veterinária e Zootecnia, Universidade Estadual Paulista, Botucatu, SP, Brasil

Submitted: June 19, 2006; Approved: October 13, 2006

\begin{abstract}
The vaccinal antibodies interference represents one of the Microscopic Agglutination test - MAT limitation in the animal leptospirosis serum diagnosis. Prospective studies showing the dimensions of this effect are rare in buffaloes. This study aimed to determine the anti-Leptospira serum agglutinin profile in vaccinated female buffaloes using two types of commercial vaccines against leptospirosis: bacterin (whole bacterial cell) and purified outer membrane and to evaluate the vaccinal interference on serum diagnosis. Three groups of 11 adult buffalo females were established: G1-control, non-vaccinated, G2- vaccinated with bacterin vaccine with six serovars, G3- outer membrane purified vaccine with five serovars. A booster dose was administrated 30 days after the first vaccination (dpv) and two re-vaccinations six months a part (210 and $390 \mathrm{dpv})$. Serum samples were collected on days $0,15,40,45,60$ and every 30 days until 540 dpv. G1, G2 and G3 serum samples were submitted to MAT with the serovars present in the vaccines. G1 remained always negative. Both vaccines induced serologic responses in MAT at $150 \mathrm{dpv}$ against all serovars and they revealed maximum titers around 45 and 60dpv as follows: Pomona: G2 (1600) and G3 (3200); Hardjo: G2 and G3 (1600); Wolffi: G2 (800) and G3 (1600); Icterohaemorrhagiae: G2 and G3 (800); Grippotyphosa: G2 and G3 (200) and Canicola: G2 (NR) and G3 (400). Even though, the Wolffi serovar is not present in the purified outer membrane vaccine, G3 showed a response to that serovar, probably due to cross reaction to the serovar Hardjo. The G3 titers were higher and appeared earlier than in G2, but with similar serologic profiles. At the re-vaccination there was an increase on agglutinin levels, but of less intensity than those previously observed. After six months from the second revaccination ( $540 \mathrm{dfv}$ ), G2 and G3 were almost negative, which demonstrated the short diagnostic interference.
\end{abstract}

Key word: buffalo leptospirosis, vaccination, serum diagnosis, MAT

\section{INTRODUCTION}

The extensive system of raising buffaloes that provides access to a diversity of ecosystems (rivers, creeks and water reservoirs) and the close contact with bovine herds are the mainly risk factors for leptospirosis infection; which can be manifested by abortion, infertility, weak newborns, and finally decreasing of reproductive and productive rates (9). The animal leptospirosis diagnosis is routinely performed by the detection of agglutinins anti-Leptospira spp. on serum sample, but it can suffer interference by the antibodies induced by vaccination $(2,10)$, compromising the decisions made about treatment and control measures. Although, buffaloes have been considered a viable alternative of protein production from animal source in Brazil, there are very few studies approaching the humoral response provided by the vaccination in this animal specie. The present trial aimed to determine anti- Leptospira spp. agglutinin profile on serum samples of females buffaloes

*Corresponding Author. Mailing address: Av. Cons. Rodrigues Alves, 1252, CEP 04014-002, São Paulo, SP, Brasil. Tel.: (11) 5087-1770. E-mail: genovez@biologico.sp.gov.br 
vaccinated against leptospirosis, using two types of commercial vaccines: bacterin (whole bacterial cell) and purified outer membrane, and also to evaluate the prospective interference of vaccine titers on serum diagnosis.

\section{MATERIALS AND METHODS}

Adult buffalo females (Bubalus bubalis) crossbred from Murrah (2 to 10 calving), clinically healthy and non-vaccinated against leptospirosis were maintained in a semi-intensive system in the Department of Production and Exploration Animal from the College of Veterinary Medicine and Animal Science, Universidade Estadual Paulista- Botucatu-São Paulo. The animals were maintained on identical sanitary conditions during the whole experimental period: no access to areas with superficial water, receiving treated water provided by a public company, feeding with commercial concentrated and do not have contact with other animal groups or species. Serum samples were collected before vaccination (day 0), and submitted to Microscopy Agglutination test (MAT) using Australis, Bratislava, Autumnalis, Butembo, Castellonis, Bataviae, Canicola, Whitcombi, Cynopteri, Grippotyphosa, Javanica, Panama, Pomona, Pyrogenes, Hardjo, Wolffi, Sherminai, Tarassovi, Andamana, Icterohaemorrhagiae, Copenhageni, Hebdomadis, Patoc and Sentot serovars (2). It was considered reactors the serum presenting $100 \%$ of agglutination at $\geq 1: 25$ dilution and the animal was not included in the test. Three groups of 11 non-reactor adult buffalo females were established: G1 (control) received $2.0 \mathrm{~mL}$ of sterile saline solution, $\mathrm{IM}$; G2 received $3.0 \mathrm{~mL}$, IM of bacterin vaccine containing serovars: Canicola, Icterohaemorrhagiae, Grippotyphosa, Pomona, Hardjo and Wolffi. G3 received 5.0 mL, IM of purified outer membrane vaccine with the same serovars above, except for the Wolffi serovar. The groups received a booster dose at 30 days past first vaccination (dpv) and the re-vaccinations at 210 and $390 \mathrm{dpv}$. The selected non-reactor animals had the serum samples collected at 15, 30, 45, 60 and every 30 days until $540 \mathrm{dpv}$, submitted to MAT with only the serovars present in the vaccines, using a serial dilution with ratio two.The final titer was the highest dilution showing at least $50 \%$ or more leptospires agglutinated (2). The selected non-reactor animals had the serum samples collected at 15,30, 45, $60 \mathrm{dpv}$ and every 30 days until $540 \mathrm{dpv}$, submitted to MAT with only the serovars present in the vaccines. For the serovars contained in the vaccine, the geometric means of serum agglutinin titers obtained by MAT at G1, G2 and G3 were performed by Graph Pad InStat for Windows. The results were submitted to Kruskal-Wallis, a non- parametric test and compared by another non-parametric test of Dunn's Multiple.

\section{RESULTS}

The Figures 1 to 6 present the geometric means of titers of agglutinins, in each group of animals, for the serovars present in the vaccine. The geometric means of agglutinin titers differ significantly $(p<0,05)$ at 15,45 , and $60 \mathrm{dpv}$ between $\mathrm{G} 2$ and $\mathrm{G} 3$ for various serovars. G3 reached significantly different levels from G1 regarding all serovars in the vaccine at $15 \mathrm{dpv}$, while G2 presented no difference. There was a difference between $\mathrm{G} 2$ and G3 only for serovars Icterohaemorrhagiae and Canicola. At 30 $\mathrm{dpv}, \mathrm{G} 3$ presented a significant difference $(\mathrm{p}<0,05)$ in relationship to the control (G1) for the following serovars: Icterohaemorrhagiae, Canicola, Pomona and Wolffi, while G2 presented a difference only for Hardjo. When G2 and G3 were compared, the differences were observed only for Canicola serovar. At 15 days after the second vaccination ( $45 \mathrm{dpv}$ ), there was a difference for Icterohaemorrhagiae and Canicola the serovars (G1 vs G2) and for six serovars, between G1 and G3. Icterohaemorrhagiae was the only serovar that presented no difference between $\mathrm{G} 2$ and G3. The first semester re-vaccination (60 to $210 \mathrm{dpv}$ ) presented no difference between G1 and G2 (p>0,05), except for Hardjo and Wolffi serovars, and both at $60 \mathrm{dpv}$. There were differences in many collection points for all serovars between G1 and G3; $\mathrm{G} 2$ and G3. After 30 days from the first re-vaccination (day 240), G1 and G2 presented differences only for Pomona, while G1 and G3 were different for Icterohaemorrhagiae, Grippotyphosa, Pomona, Hardjo and Wolffi serovars. However, no differences were detected between $\mathrm{G} 2$ and $\mathrm{G} 3$ regarding all serovars. These differences were not constant, oscillated throughout the experimental observation period.

\section{DISCUSSION}

The vaccination, using commercial bacterin vacine against leptospirosis is the most important tool for this disease control in production animals (11). The present study used two commercial vaccines for bovine, one of those was prepared upon inactivated culture of six serovars of Leptospira spp and the other was composed by purified outer membrane of five serovars, both added with adjuvant.

The three groups were maintained in the same sanitary conditions described above, G1 showed low oscillatory serologic titers, always inferior to 100 (all animals negative), which is represented by the geometric means of serum agglutinin titers always below 2, confirming the efficacy of the sanitary conditions for the animal raising. Once being confirmed negatives before vaccinations, all vaccinated buffaloes, either with bacterin or outer membrane vaccine, presented positive serological responses, which began at within the $15 \mathrm{dpv}$ for all serovars contained in the vaccines. The same fact was already reported (9), all buffaloes presented seroconversion to the vaccine serovars Pomona, Canicola, Hebdomadis, Tarassovi and Shermani at $15 \mathrm{dpv}$.

The serological monitoring of animals throughout 540 days after first vaccination revealed maximum titers around 45 and 60 $\mathrm{dpv}$, for both vaccines and all serovars. The same responses 
were described by Nardi Júnior (7), observing maximum titers by MAT between 45 and 60 days after vaccination of 17 buffalo calves with pentavalent bacterin (Icterohaemorrhagiae, Canicola, Grippotyphosa, Pomona, Hardjo), showing the similarity of the antibody responses upon the use of different commercial vaccines.

The Figures 1-6 presented similar serological profiles for both vaccines with close serological responses, but with different titers intensity. G3 was superior to G2 in the most of the time and for the most of the serovars. G3 seroconverted earlier and showed higher titers when compared to G2. In general, six months after the second dose (210 dpv), G2 and G3, had no positive animals (titers <100), with exception for the serovar Pomona (G2) presenting one animal with titer 100 and G3 presenting three animals with titer 100, and for Hardjo, G2 and G3, with one animal per group presenting titer 100 .

The persistency of agglutinins from the vaccines during three months was observed in buffalo calves previously vaccinated with a pentavalent bacterin and the better vaccine response was reached in animals that received two doses, in comparison with a single dose group (10). After this period, the titer geometric mean rarely exceeded the cut off point (titer 100). In the present paper, this fact was not observed for Pomona serovar, which showed elevated means at 240 and $420 \mathrm{dpv}$ in G3 (Figures 1 to 6). At $210 \mathrm{dpv}$ (after the first re-vaccination) occurred a low increasing titers and with rapid tendency to become negative when compared with $30 \mathrm{dpv}$ (booster). This condition was also observed after the second re-vaccinations, but a progressive decline in a proportion of positive animals by MAT

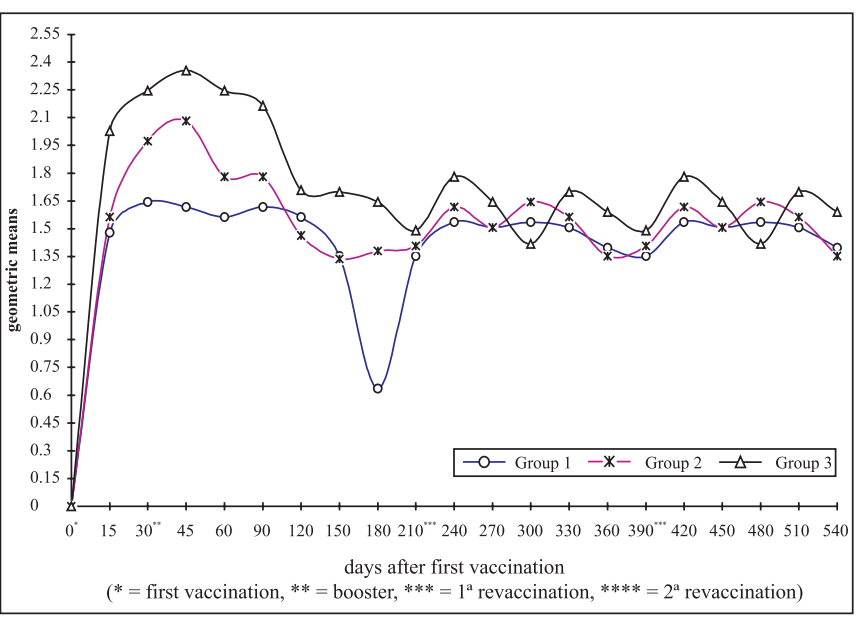

Figure 1. Geometric means of agglutinin titers anti- Leptospira spp. serovar Icterohaemorrhagiae in serum of vaccinated buffaloes using two types of commercial vaccines: G2-Bacterin and G3 Outer Membrane Vaccine. G1-control group . São Paulo, 2005.

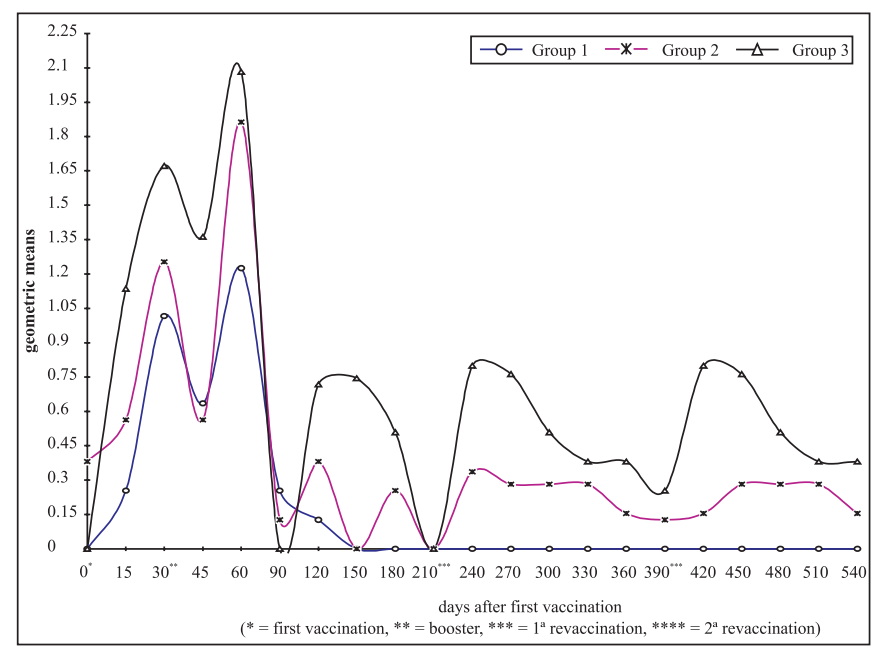

Figure 2. Geometric means of agglutinin titers anti- Leptospira spp. serovar Canicola in serum of vaccinated buffaloes using two types of commercial vaccines: G2-Bacterin and G3 Outer Membrane Vaccine. G1-control group. São Paulo, 2005.

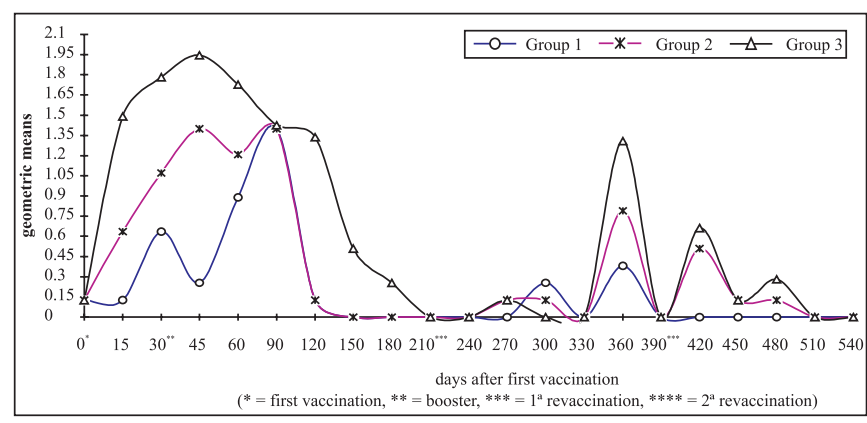

Figure 3. Geometric means of agglutinin titers anti- Leptospira spp. serovar Grippotyphosa in serum of vaccinated buffaloes using two types of commercial vaccines G2-Bacterin and G3 Outer Membrane Vaccine. G1-control group . São Paulo, 2005.

occurred eight months after the leptospirosis herd control measures had been applied, and all serological reactions were eliminated seven years post the beginning of vaccination $(5,6)$. It was observed that a bovine herd endemically infected by the Hardjo serovar and vaccinated with six serovar bacterin (Icterohaemorrhagiae, Canicola, Grippotyphosa, Pomona, Hardjo e Wolffi) was able of serum conversion, but on two semester re-vaccinations, the proportion of reactors decreased progressively (3).

In the present study, at $540 \mathrm{dpv}$ (6 months after the second re-vaccination), the two treated groups no more presented positive animals for all serovars, showing no interference of the vaccination on the diagnosis after this period. Thus, in average, 


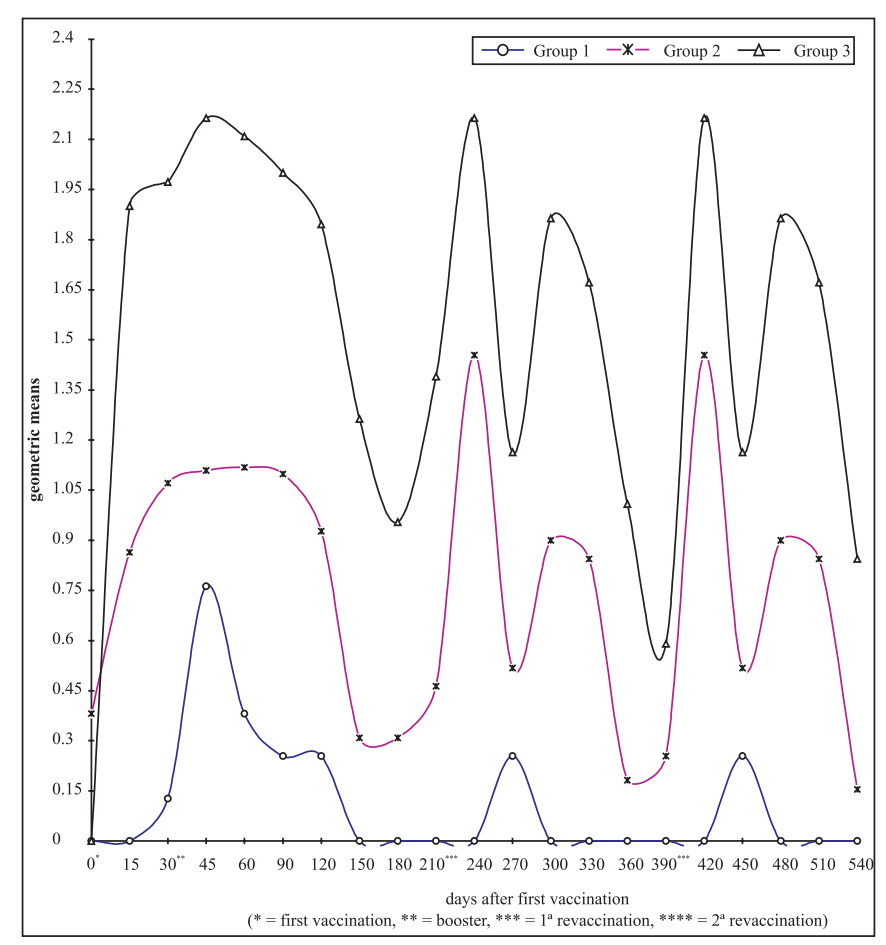

Figure 4. Geometric means of agglutinin titers anti- Leptospira spp. serovar Pomona in serum of vaccinated buffaloes using two types of commercial vaccines: G2-Bacterin and G3 Outer Membrane Vaccine. G1-control group. São Paulo, 2005.

six months after each re-vaccination, positive animals were no more detected by MAT. This test does not allow any conclusion about protection level conferred by vaccine against leptospirosis, however, the monitoring of progressive titer decreasing can be useful to evaluate vaccine efficiency. High titers $(>1,600)$ may mean that another infecting leptospira strain or a new serovar entered into the herd stimulating high humoral immune responses, and indicating escape from vaccine protection. In this case, a review in the vaccination program and sanitary management of the herd would be necessary (3).

According to other publication, the interference of vaccine antibodies in MAT, in three herds of buffaloes submitted to the control measures for leptospirosis (chemotherapy and systematic vaccination) was described and compared to a control herd, which was neither treated nor vaccinated (8). Vaccinated herds presented a significant higher percentage of reactors than the control herd showing an interference of vaccination on the results of MAT; even respecting the interval of four to six months between the last vaccination and the blood collection (8). One explanation for this disagreement would be the inclusion of non-reactor animals that serum converted after vaccination and became negatives throughout the re-vaccinations. Other

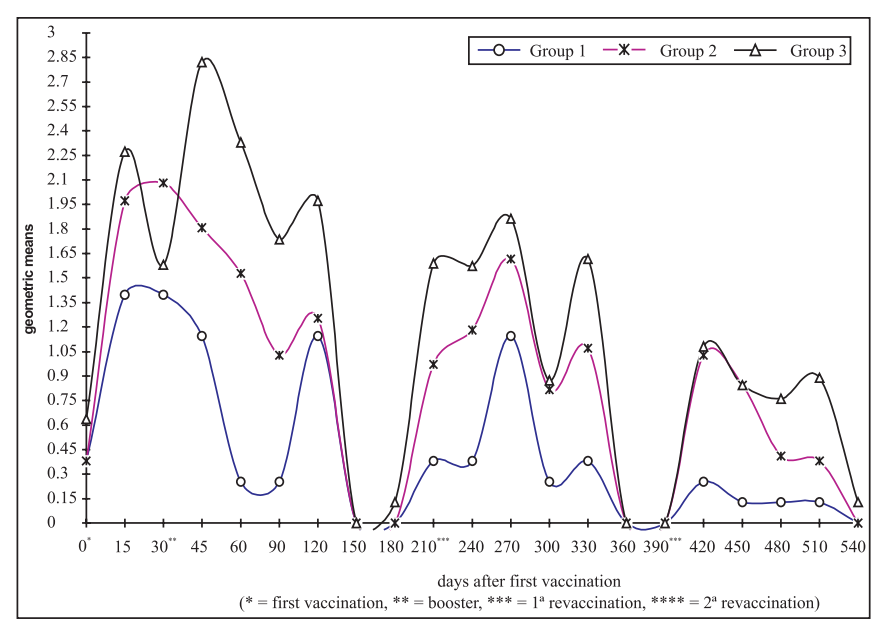

Figure 5. Geometric means of agglutinin titers anti- Leptospira spp. serovar Hardjo in serum of vaccinated buffaloes using two types of commercial vaccines G2-Bacterin and G3 Outer Membrane Vaccine. G1-control group . São Paulo, 2005.

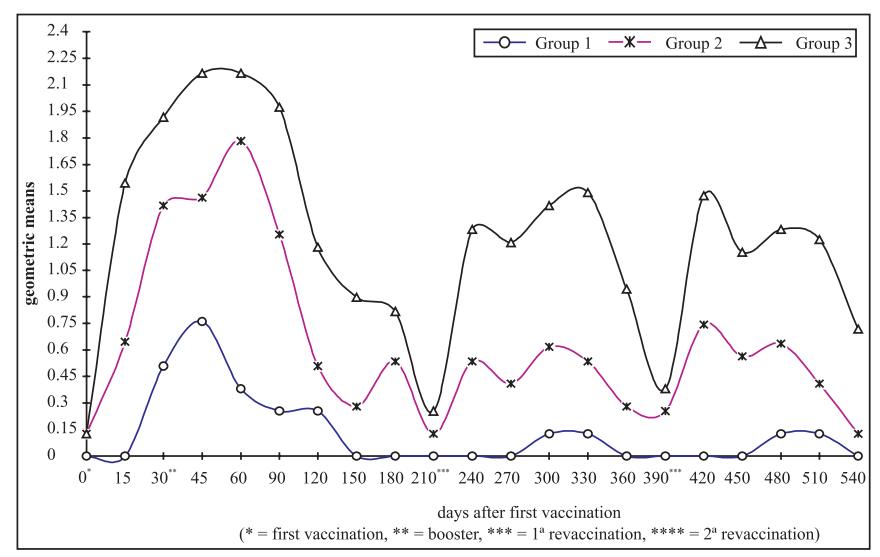

Figure 6. Geometric means of agglutinin titers anti- Leptospira spp. serovar Wolffi in serum of vaccinated buffaloes using two types of commercial vaccines. São Paulo, 2005.

hypothesis would be related to the strains used in the preparation of commercial vaccines, specially the maintenance and growth conditions of vaccine strain seeds, and also in the number of serovars and the kind of adjuvant used (12). Four adult buffaloes experimentally infected with the serovar Pomona, rendered a maximum titer of 800 at 14 and 19 days after inoculation and becoming negative at 72 days, demonstrating that even using live virulent culture, Leptospira spp. can induce a low and fugacious serological response (4).

In despite of the similar profiles observed by the two vaccines, the geometric means of agglutinin titers presented a 
significant difference $(\mathrm{p}<0,05)$ for Pomona, Canicola and Wolffi serovars; but they were rare for Icterohaemorrhagiae, Grippotyphosa and Hardjo serovars. The Pomona serovar presented nine points statistically different and Wolffi and Canicola serovars presented five points each. These differences were more constant before the first re- vaccination $(210 \mathrm{dpv})$ due to oscillatory titers. Wolffi serovar presented statistic differences between $\mathrm{G} 3$ and $\mathrm{G} 2$, being $\mathrm{G} 3$ superior in agglutinin levels in all analyzed points. Even though, this serovar was not part of the outer membrane vaccine (G3), it was observed a cross reaction with Hardjo, since they both belong to the same serogroup Sejroe $(1,11,13)$. The bacterins prepared with separated strains of Hardjo and Pomona serovars can promote a cross serological response. Nevertheless, the bacterin containing the serovar Wolffi induces higher titers of serum agglutinins against Hardjo serovar than against homologous serovar (11).

In conclusion, the serological monitoring of vaccinated herds can be an interesting tool to evaluate the status of protection provided by the vaccine, but always having in mind that a significant increase of vaccine serovar titers, or even an alteration of herd serological profile can reflect a failure in the capability of that vaccine protection and thus it demands a review on prophylaxis measures. In this case, the attempt of leptospira isolation could be of great help for the knowledge of its virulence and capability of dissemination, including it in a new immunization protocol.

\section{ACKNOWLEDGMENT}

This work was supported by FAPESP-Fundação de Amparo à Pesquisa do Estado de São Paulo

\section{RESUMO}

\section{Interferência de de anticorpos vacinais no diagnóstico sorológico da leptospirose em búfalas vacinadas com dois tipos de vacinas comerciais}

A persistência de anticorpos vacinais representa um dos entraves para o sorodiagnóstico da leptospirose. Raros estudos dimensionam prospectivamente esse efeito na espécie bubalina.

O presente trabalho objetivou traçar o perfil de aglutininas séricas anti-Leptospira spp. em búfalas vacinadas contra leptospirose com dois tipos de vacina comercial : bacterina e de membrana externa purificada e avaliar a interferência temporal dos títulos vacinais no sorodiagnóstico. Três grupos de 11 fêmeas bubalinas adultas: G1- controle não vacinado, G2 vacinado com bacterina contendo seis sorovares e G3- recebeu vacina com membrana externa purificada de cinco sorovares, receberam reforço 30 dias pós primo vacinação (dpv) e duas revacinações semestrais nos dias 210 e 390. Foram colhidas amostras sorológicas nos dias 0,15, 30, 45, 60 e a cada 30 dias até $540 \mathrm{dpv}$ e analisadas pela reação de Soroaglutinação Microscópica-SAM frente aos sorovares presentes nas vacinas. G1 manteve-se sempre negativo. Ambas vacinas induziram resposta sorológica na $\mathrm{SAM}$ aos $15^{\circ} \mathrm{dpv}$ para todos os sorovares e revelaram títulos máximos ao redor do $45^{\circ}$ e $60^{\circ}$ dpv.: Pomona: G2 (1600) e G3 (3200); Hardjo: G2 e G3 (1600); Wolffi: G2 (800) e G3 (1600), Icterohaemorrhagiae: G2 e G3 (800), Grippotyphosa: G2 e G3 (200) e Canicola: G2 (NR) e G3 (400). Apesar da vacina de membrana externa não possuir o sorovar Wolffi, G3 revelou resposta para este sorovar, provavelmente pelo sorovar Hardjo vacinal. Os perfis sorológicos representados graficamente pela média geométrica dos títulos de aglutininas foram semelhantes, porém em G3 mais precoces e mais elevados que G2. Na revacinação houve aumento do nível de aglutininas, porém de menor intensidade que o anterior; e ao final de seis meses da segunda revacinação (540 dpv) eram quase nulos, demonstrando curta duração da interferência ao diagnóstico.

Palavras-chave: leptospirose, búfalos, vacinação, sorodiagnóstico, SAM

\section{REFERENCES}

1. Costa, M.C.R; Moreira, E.C.; Leite, R.C.; Martins, N.R.S. (1998) Avaliação da imunidade cruzada entre Leptospira hardjo e $L$. wolffi. Arq. Bras. Med. Vet. e Zootec., 50(1), 11-17.

2. Faine, S.; Adler, B.; Bolin, C.; Perolat, P. (1999). Leptospira and Leptospirosis. MediSci., Melbourne, Australia.

3. Genovez, M.E.; Oliveira, J.C.F.; Castro V.; Ferrari, C.I.L.; Scarcelli, E.; Cardoso, M.V.; Paulin, L.M.S.; Lança Neto, P. (2004). Serological profile of a Nelore herd presenting endemic leptospirosis and submitted to vaccination. Arq. Inst. Biol., São Paulo. 71(4), 411-416.

4. Girio, R.J.S.; Mathias, L.A.; Yanaguita, R.M.; Cabrera, M.F. (1988), Evolução dos títulos de anticorpos séricos em búfalos jovens infectados experimentalmente com Leptospira interrogans sorotipo pomona. Rev. Microbiol., 19(4), 405-411.

5. Hanson, L.E. (1977). Immunology of bacterial diseases with special reference to leptospirosis. J. Am. Vet. Med. Assoc., 170(9), 991994.

6. Moreira, E.C. (1994). Avaliação de métodos para erradicação de leptospiroses em bovinos leiteiros. Minas Gerais, Brasil, 110 p. (PhD. Thesis. Escola de Medicina Veterinária-Universidade Federal de Minas Gerais).

7. Nardi Junior, G.; Ribeiro, M.G.; Vasconcellos, S.A.; Megid, J.; Jorge, A.M.; Geronutu, L.; Morais, Z. M. Perfil de aglutininas anti-Leptospira em bezerras búfalas vacinadas com bacterina pentavalente contra leptospirose. Arq. Bras. Med. Vet. Zootec., Belo Horizonte, MG. 2005. (no prelo).

8. Oliveira, J.C.F. (2000). Isolamento de Leptospira santarosai sorovar Guaicurus em búfalos (Bubalus bubalis) do Vale do Ribeira/SP, Brasil: Efeito de dois esquemas de controle da leptospirose sobre o desempenho reprodutivo das búfalas. São Paulo, Brasil, 63p. (PhD. Thesis. Faculdade de Medicina Veterinária e Zootecnia, USP).

9. Radostitis, O.M.; Gay, C.C.; Blood, D.C.; Hinchcliff, K.W. (2000) Veterinary Medicine, W.B. Saunders

10. Rao, A.S.; Keshavamurthy B.S. (1985). Study of the immune response of buffalo calves to heat-killed pentavalent leptospiral vaccine. Indian Vet. J., 62, 357-361. 
11. Tabata, R.; Scanavini Neto, H.; Zuanaze, M.A.F.; Oliveira, E.M.D.; Dias, R.A.; Morais, Z.M.; Ito, F.H.; Vasconcellos, S.A. (2002). Cross neutralizing antibodies in hamsters vaccinated with leptospiral bacterins produced with three serovars of Serogroup Sejroe. Braz.J. Microbiol., São Paulo, 33, 265-268.

12. Tizardi, I.R. (1996) Vacinação e vacinas. Ed. Roca, São Paulo, Brasil.
13. Vasconcellos, S.A.; Barbarini Júnior, O.; Umehara, O.; Morais, Z.M.; Cortez, A.; Pinheiro, S.R.; Ferreira, F.; Fávero, A.C.M.; Ferreira Neto, J.S. (1997). Leptospirose bovina. Níveis de ocorrência e sorotipos predominantes em rebanhos dos Estados de Minas Gerais, São Paulo, Rio de Janeiro, Paraná, Rio Grande do Sul e Mato Grosso do Sul. Período de janeiro a abril de 1996. Arq. Inst. Biol., 23(3), 406-407. 